
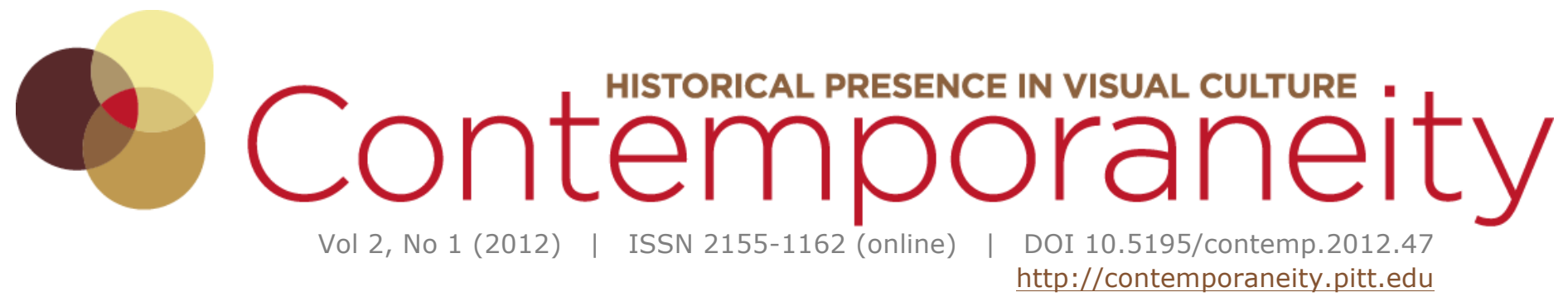

\title{
An Interview with Lucy Skaer of Henry VIII's Wives
}

\author{
Brianne Cohen
}

\begin{abstract}
This interview took place on January 26, 2012 over Skype. I, Brianne Cohen, posed a series of questions to Lucy Skaer about three of Henry VIIIs's Wives' artworks presented in this volume of Contemporaneity - Spiral Betty (2004), Mr. Hysteria (2005), and The Returning Officer (2009) - in order to draw out thematic connections not only among the art collective's moving-image installations, but also throughout their larger, diverse oeuvre. The six members of Henry VIII's Wives live and work in different cities, but have collaborated and exhibited together since 1997, primarily in Europe. I am thankful to Lucy Skaer for her thoughtful answers and to Henry VIII's Wives for permission to present their video and filmic work.
\end{abstract}

\section{About the Author}

Lucky Skaer is one of the six members of Henry VIII's Wives, as well as an independent artist based in New York. Brianne Cohen is an editor of Contemporaneity. 


\section{An Interview with Lucy Skaer of Henry VIII's Wives}

This interview took place on January 26, 2012 over Skype. I, Brianne Cohen, posed a series of questions to Lucy Skaer about three of Henry VIIIs's Wives' artworks presented in this volume of Contemporaneity - Spiral Betty (2004), Mr. Hysteria (2005), and The Returning Officer (2009) - in order to draw out thematic connections not only among the art collective's moving-image installations, but also throughout their larger, diverse oeuvre. The six members of Henry VIII's Wives live and work in different cities, but have collaborated and exhibited together since 1997, primarily in Europe. I am thankful to Lucy Skaer for her thoughtful answers and to Henry VIII's Wives for permission to present their video and filmic work.

Brianne Cohen: To begin with, can you explain how your group formed, and why you chose the name "Henry VIII's Wives"?

Lucy Skaer: We basically all studied together, and part of our study was to do public art projects. We found that we just kind of naturally teamed up to do those because they were all projects that had to be outside the gallery or school. So we formed a natural squad for those, and then when we left school we applied to do a show at Transmission Gallery as a group. We'd shown together a couple of times before then as a group but with our individual work. The idea to actually form a collaboration came up when Transmission asked us for a more clear proposal of what we were going to do. So then we thought, "Why don't we actually collaborate together rather than just make another group show?" So that's how the collaboration came about, and as for the name, it was actually the name of our first show. The exhibition title was "Henry VIII's Wives," and that migrated to being our name because it just seemed to fit somehow, in the way that it doesn't really fit because it doesn't describe any of us [laughs].

The title for the show was made in response to the death of Lady Diana. The show was that winter, and she'd been killed in the autumn. So it was inspired by that huge media response and the idea of other royal deaths. The poster had six small thumbnail drawings of her crashed car, so there was a direct reference.

BC: Let's begin now with Spiral Betty. Can you tell us what the title of this piece signifies, and why does it seem to have this reference to Robert Smithson's Spiral Jetty $(1970) ?$

LS: Well yes, although the work came from quite a serious point, the title was a joke. We were working with this gallery, Iris Kadel, in Karlsruhe, and she was quite keen to market our work and take it to art fairs and things. There was something about the way the group worked that didn't take this kind of proposition very seriously, so we called it something that we thought she would have a hard time explaining [laughs]. But also it seemed in keeping with our general mood, that we would take some art references and use them as a form of nonsense. Funnily, Rosemarie Trockel has also used that title, which we didn't know about. So we're in good company. 
Regarding Smithson, the course that we studied was environmental art, so Smithson was a big reference in our education. Land art and public art were something to be revered, so I think it was a kind of hangover from that as well.

BC: Right, can you tell us quickly which school you're referring to?

LS: Yes, Glasgow School of Art had this department that was really successful in the 90s and early 2000s, and taught the philosophy that context is half the work. So the viewing situation for the work had to be taken into account, and you couldn't just assume you had a certain audience. You couldn't assume that you had a white box.

BC: So in the video installation, it's clear that two women are engaged in some kind of dialogue, but it's quite disconnected and fragmented. Can you tell us how you staged and edited this piece in order to achieve such an effect?

LS: This was actually the second time we'd done this kind of format. We arrived at the script from a series of interviews. This one was generally interviews with "the good" and interviews with "the bad." It's making a huge assumption that's not viable about who in society is good and who is bad, and playing with what they say - kind of out of the horse's mouth. We interviewed prisoners in the north of England and prostitutes for our "bad" camp, and the "good" camp was church-goers, charity workers, members of the Women's Institute, which is a quite village-like association in the UK. Then we took their words and knitted them together into this script, so that one woman in the film says lines put together from the stereotypical bad, while the other one speaks the lines of the "good." It's a conversation between the "good" and "bad," but the way it actually comes across in the film is that one character seems to take the moral high ground, and the other one doesn't. What they actually say is impossible to separate into "good" and "bad."

BC: In the artwork, the women are also blind and elderly. In several of the group's pieces, you have employed the help of elderly people, blind people, or people who suffer from dementia (as in the case of The Returning Officer). Do you feel they have a special viewpoint to offer in your edited conversations?

LS: I guess what we wanted to do was find a pre-existing group of people, so that we weren't choosing people for how they looked or what their class was, or where they were from or anything like that. We tapped into this secondary characteristic that they'd already used to define themselves as a group. The first time we made a film with blind people was in our show Light Without Shadow, and we were actually just quite interested in how they were on the screen after we made that. So with the one we shot in New York [Spiral Betty], we wanted to further pursue that - the way that the women are on the screen, and the way that they say lines and respond to each other's speech.

BC: In the background of the women's conversation, one views the skyscrapers of New York. This is your first piece exhibited in the United States, and it was also produced only one year after George W. Bush's State of the Union address labeling certain countries along 
an "axis of evil." Do you think such post-9.11.01 labels and fears, between the "good guys" and the "bad guys," informed the backdrop of this piece?

LS: The building you see out of the window is the United Nations, and we'd originally wanted to film it in the UN. So we were thinking about that kind of angle of the work with this - the whole idea that at that point "good" and "evil" became really politicized. We wanted to complicate that.

BC: Ok, so let me move on now to Mr. Hysteria. This piece hinges on the idea of fear and hysteria. Can you tell us what kind of research you did for the preparation of this piece, and how you collected statements to compose its script?

LS: We made Mr. Hysteria for the show Populism, which was touring around various venues in Europe, and we wanted to make something that had more of a narrative than Spiral Betty. So we were interviewing about these moments where reality and daily life became overwhelmed by something and detached, or in a space where that detachment was a kind of normal situation. For example, we filmed in the stock exchange in Berlin, where there's a high degree of speculation, I guess, on what certain realities are. And we interviewed people about mass experiences like big political marches or the fall of the Berlin Wall. We tried to put these together in a narrative sequence. So we'd interview people about, say, an approaching crowd or being part of a crowd. Then we'd interview someone like a long-distance runner about running a race, so we'd have that movement from "approaching crowd" to "running," and then to "arriving in a space." We interviewed people about coming home after a long time away. We tried to add a narrative dimension.

Our plot was basically this kind of mounting mass feeling - a movement (like running) and an arrival and the description of an object in space. One object we gave people to describe was a rope knotted into a noose; another one was an alarm clock that had stopped at a certain time. I can't remember what the other objects were, but again, the whole script is made up from these interviews. We didn't write any part of it. It is put together to have a recognizable structure but still maintain this kind of disjunctive strangeness, which is heightened by the way it's edited, the way the camera moves, these different non-actors, and various locations. The locations are the stock exchange, a maternity hospital, a prison/police station with cells in Lithunia, and a newspaper archive in Berlin.

BC: Can you talk more about why you chose those locations?

LS: I guess with the stock exchange it was this element of speculation and divorce from reality - that it felt like a hothouse of speculation in there. And the maternity hospital for its links with hysteria, being this "disease of the womb," going back to the very early definitions of hysteria. The police station - I think because it's kind of this odd, in-between place.

BC: Yes, Sirko Knüpfer [another member of Henry VIII's Wives] described the police as "detectors of mismatched reality."

LS: He put it well. And the newspaper archive is a place where reality is finally settled on and defined in a way. 
BC: So you've described how you're trying to achieve a certain feeling in the video, and we see in it that there's a quickening of pace from beginning to end, and different men and women in various scenes seem to replace each other anonymously. Their voices overlap and carry through as if in one conversation, building to a pitch at the conclusion. How do you see these people relating to each other across the span of the film? Are they mimicking a type of rumor or hysteria?

LS: The way that I see them is that they're both enacting and telling at the same time, like the relationship an oracle might have to a society, that they're these "tellers" rather than what they're saying being particularly applicable in a certain way. They're more abstractly, or not literally, describing or saying. I think we were interested in that mode.

BC: How does that connect to the show you made it for, Populism, which was an exhibition that was particularly interested in the growing strength of populist parties throughout Europe in the last fifteen years? How did you approach the idea of populism through this piece?

LS: The structure of our piece leads towards a kind of crisis, from this group movement to a slightly overwrought description of an object, from this mass movement to moment of subjectivity. I think we were looking at a kind of isolation, or bringing about a point of isolation between these people. They're artificially united in our film with what they're doing and what they're talking about, but there isn't actually cohesion between them.

BC: Ok, moving on to the last piece featured here, The Returning Officer - this threescreen video installation is different from Spiral Betty and Mr. Hysteria in the sense that you did not conduct interviews or collect statements for it. It is a three-part, silent "film" accompanied by an organ, literally situated underneath two of the back-to-back screens. Why did you decide to shift strategies for this piece?

LS: Well we started in a different place for this piece. We were shooting on film, which we hadn't done before, and that leads to sound being a problem. Part of it was an interest in the image over speech, which is why we made it in film. I would almost put The Returning Officer in a different series than the other ones, although it has some tactics in common, like using people in the places where they live and work. And it's a multi-screen, almost like a disjointed narrative bringing together these disparate places. Instead of a bringing together of interviews and places, it's more that the content just comes from the place. So with the poppy field, we used the family who owned the poppy field in their poppy field, and we directed them a bit based on a scene from the Wizard of Oz. But that was just more a way of having some kind of direction for them - getting them started and then letting them do their own thing.

With the house in Belgrade where we shot, it was quite a strange context [the Legacy House in Belgrade, Serbia, officially known as "Legacy of Milica Zorić and Rodoljub Čolaković," and now owned by the Museum of Contemporary Art]. What we wanted to do is just make a very simple narrative: this guy fixes the lights inside this house, and he manages to fix them in time before the evening gets darker and darker. So as night falls, the lights will come on. He collapses in the garden, but that collapsing is a reenactment of something that happened in the building. The building was part of the museum in Belgrade. The museum was taken over during the Milošević regime, and the house that had been a residency for the museum had been turned into a kind of gambling den and brothel. That's 
how we found it. It had tons of cigarette burns on the floor and a very unpleasant feeling to it. One of the gangsters who'd run that place had been shot in the garden, so we made this reenactment with the caretaker - I suppose bridging the reality of the caretaker, who was there to do things such as fix the lights, with this recent history of the building.

BC: And the other screen?

LS: The third film was this organ builder's house in Vilnius, where'd actually gotten an organ pipe built by him [for an earlier piece, The lowest note on an organ = the length of a human fingernail grown since $1730=8 H Z /$ subsonic (2005)]. We'd gone to visit him and were just really amazed by the structure of his house because it was built around the negative shape of a church organ, so that he could build the pipes inside the house. It was really a kind of bizarre, specialized architecture, and the house was ramshackle. But the organ pipes inside were absolutely perfectly crafted.

There was a certain idea in those films [The Returning Officer] about the building somehow achieving its potential. Very early in the Belgrade film, in our first proposal, we wanted to make an installation in the house that filled it with light and noise, and it would just play in that neighborhood. That got transmuted into the film - this idea of filling the house with light. And similarly with the organ builder's house, there was this moment of realizing the potential of this whole house becoming a musical instrument. In that film, the organ builders have a fan they hook up to the organ pipes in order to make them sound, so that they can tune them. Our film with its live accompaniment - it's the picture of this happening. The organ pipes having this air flow through them is matched with this live sound of the organ, which gets louder and louder and more discordant.

BC: And there's also a scene with elderly people that we see, right?

LS: Yes, there's a cutback from the poppy field to these elderly people in a home near Bristol. It's almost like they're the built-in audience. And part of what we were interested in with the poppy fields is this dual idea of forgetting on one hand and remembering on the other - the opium poppy versus the red poppy. There's a play on oblivion with those people with dementia, but also on the red poppy, the wartime remembrance poppy.

BC: You also produced a trailer for the piece, which is still available on Youtube. Can you tell us how you created this and how it functions within the larger project?

LS: Yes, quite often with the works, such as Mr. Hysteria or Spiral Betty, we take existing material, feed it through another process, give it back to other people, and then take it back from them, etc... So we gave all of our footage to a commercial editor to see what he would put together from it, knowing that it would come out very differently from what we would edit [laughs]. It was a content-generating thing - we wanted to simultaneously undermine our artistic presentation with a commercial presentation that we wouldn't have made.

BC: Overall the piece seems to act like a spoof horror film. Is this an effect you intended, and does it relate at all to the fear/anxiety that we see in Mr. Hysteria? 
LS: I think there is an underlying threat in The Returning Officer, but there's also a funny humanity that you see. We didn't think about it being a horror film necessarily, but that is how it seems in the trailer certainly. I hadn't thought about it being like a horror film, although it is a spoof in some ways. I think there's something in the work that allows it to play with these quite recognized forms but also make them disconcerting by the humanity of them, the way that people - non-actors - react. We certainly never rehearsed things. It was a big part of the mechanism that we used to make the films - that we kept them being very unrehearsed and very raw.

BC: This seems to be an overarching aspect of your work - the idea of playing with narratives, the idea of storytelling or history-writing, for that matter. Would you say that this is one of your larger goals as a group?

LS: Yes, I think back from our very first works together, we were playing around with the idea of reenactment, and particularly reenactment of key things in human development like making fire or fending off a pack of dogs with torches. So I think that theme goes all the way through our work, and became increasingly complex and convoluted. The project that we're dealing with a lot now is the Tatlin's Tower project, which is, again, a reenactment of a certain point of history, but a complete breakdown of it and an ironic staging of it.

BC: Can you give us a quick sense of what that project is about?

LS: It's an ongoing attempt to build Vladimir Tatlin's Monument to the Third International. The original tower was designed between 1919 and 1921 and was meant to house the international communist headquarters. It was a completely radical design, and the fact that it wasn't built is often cited as a turning point in history where that branch of the Russian avant-garde - and its goal to unite art and politics - failed. So our attempt to build Tatlin's tower is to build it full size (and it was meant to be twice the height of the Empire State Building) and from the original materials, but in small pieces around the world until the whole tower exists. But it's not going to be united ever. It's always going to be kept as this disparate thing, and part of the reason we thought that would be interesting is because it seems like that set of ideas and the situation of the un-built tower has different resonances in different countries, different political environments, different social groups, as well as if it's in, say, a park or a gallery. It just seems to bring up a lot of baggage. Yes, so our project is this ongoing attempt.

BC: Do you see your group's work moving now from video and film to more public sphere projects, and what was it about video/film that attracted you?

LS: I think right from the beginning, it was an easy way that we could work together. It's a great leveler, whereas making a drawing (we have done that was well) is more problematic. Video and film seemed to bring an immediate sort of unity. And I don't know what we're going to do next... 


\section{(cc) EY-NC-ND}

This work is licensed under a Creative Commons Attribution-Noncommercial-No Derivative Works 3.0 United States License.

\section{ULIS D-Sork}

This journal is operated by the University Library System of the University of Pittsburgh as part of its D-Scribe Digital Publishing Program, and is co-sponsored by the University of Pittsburgh Press. 